\title{
Postsynaptic Serine Racemase Regulates NMDA Receptor Function
}

\author{
Jonathan M. Wong, ${ }^{1,2 *}$ Oluwarotimi O. Folorunso, ${ }^{3,4 *}{ }^{-}$Eden V. Barragan, ${ }^{1,2}$ Cristina Berciu, ${ }^{3}$ \\ Theresa L. Harvey, ${ }^{4}{ }^{-}$Joseph T. Coyle, ${ }^{3}{ }^{\circledR}$ Darrick T. Balu, ${ }^{3,4}$ and ${ }^{\circledR}$ John A. Gray, \\ ${ }^{1}$ Center for Neuroscience, University of California Davis, Davis, California 95616, ${ }^{2}$ Neuroscience Graduate Group, University of California Davis, \\ Davis, California 95616, ${ }^{3}$ Department of Psychiatry, Harvard Medical School, Boston, Massachusetts 02115, ${ }^{4}$ Translational Psychiatry Laboratory, \\ McLean Hospital, Belmont, Massachusetts 02478, and ${ }^{5}$ Department of Neurology, University ofCalifornia Davis, Davis, California 95616
}

D-serine is the primary NMDAR coagonist at mature forebrain synapses and is synthesized by the enzyme serine racemase (SR). However, our understanding of the mechanisms regulating the availability of synaptic D-serine remains limited. Though early studies suggested D-serine is synthesized and released from astrocytes, more recent studies have demonstrated a predominantly neuronal localization of SR. More specifically, recent work intriguingly suggests that SR may be found at the postsynaptic density, yet the functional implications of postsynaptic SR on synaptic transmission are not yet known. Here, we show an age-dependent dendritic and postsynaptic localization of SR and D-serine by immunohistochemistry and electron microscopy in mouse CA1 pyramidal neurons. In addition, using a single-neuron genetic approach in SR conditional KO mice from both sexes, we demonstrate a cell-autonomous role for SR in regulating synaptic NMDAR function at Schaffer collateral (CA3)-CA1 synapses. Importantly, single-neuron genetic deletion of SR resulted in the elimination of LTP at 1 month of age, which could be rescued by exogenous D-serine. Interestingly, there was a restoration of LTP by 2 months of age that was associated with an upregulation of synaptic GluN2B. Our findings support a cell-autonomous role for postsynaptic neuronal SR in regulating synaptic NMDAR function and suggests a possible autocrine mode of D-serine action.

Key words: GluN2A; glycine; NR2A; NR2B; plasticity; Srr

Significance Statement

NMDARs are key regulators of neurodevelopment and synaptic plasticity and are unique in their requirement for binding of a coagonist, which is D-serine at most forebrain synapses. However, our understanding of the mechanisms regulating synaptic D-serine availability remains limited. D-serine is synthesized in the brain by the neuronal enzyme serine racemase (SR). Here, we show dendritic and postsynaptic localization of SR and D-serine in CA1 pyramidal neurons. In addition, using single-neuron genetic deletion of SR, we establish a role of postsynaptic SR in regulating NMDAR function. These results support an autocrine mode of D-serine action at synapses.

Received June 16, 2020; revised 0ct. 23, 2020; accepted Nov. 1, 2020.

Author contributions: J.M.W., 0.0.F., C.B., T.L.H., J.T.C., D.T.B., and J.A.G. designed research; J.M.W., 0.0.F., E.V.B., C.B., and T.L.H. performed research; J.M.W., O.O.F., C.B., T.L.H., D.T.B., and J.A.G. analyzed data; J.M.W. wrote the first draft of the paper; 0.0.F. and J.A.G. wrote the paper; J.T.C. and D.T.B. edited the paper.

*J.M.W. and 0.0.F. contributed equally to this work.

J.T.C. reports consulting with Concert Pharm and holding a patent on D-serine for the treatment of serious mental illness, which is owned by Massachusetts General Hospital. D.T.B. served as a consultant for LifeSci Capital and received research support from Takeda Pharmaceuticals. All remaining authors declare no competing financial interests.

This work was supported by Jeane B. Kempner Postdoctoral Fellowship Award and McLean Hospital Presidential Award to 0.0.F., T32MH082174 to E.V.B., Whitehall Foundation \#2018-05-107 to D.T.B., BrightFocus Foundation A2019034S to D.T.B., R03AG063201 to D.T.B., a subcontract of R01NS098740 to D.T.B., US-Israel Binational Science Foundation Grant 2019021 to D.T.B., R01MH05190 to J.T.C., R21MH116315 to J.A.G., and R01MH117130 to J.A.G. We thank Haley Martin, Zaiyang "Sunny" Zhang, and Casey Sawyer for assistance in mouse breeding and genotyping.

Correspondence should be addressed to John A. Gray at john.gray@ucdavis.edu or Darrick T. Balu at dbalu@mclean.harvard.edu.

https://doi.org/10.1523/JNEUROSCI.1525-20.2020

Copyright $(2020$ the authors

\section{Introduction}

NMDARs are glutamate receptors, which have a property unique among ion channels: they require a coagonist for channel opening (Johnson and Ascher, 1987; Kleckner and Dingledine, 1988). In addition to glutamate binding to the GluN2 subunits, either glycine or D-serine must bind to the GluN1 subunits. D-serine is the primary coagonist at most mature forebrain synapses, including the Schaffer collateral-CA1 synapse in the hippocampus (Mothet et al., 2000; Papouin et al., 2012; Le Bail et al., 2015) and is synthesized in the brain by the enzyme serine racemase (SR), which converts L-serine to D-serine (Wolosker et al., 1999). However, our understanding of the mechanisms regulating the availability of synaptic D-serine remains limited.

Early studies suggested that D-serine is synthesized and released by astrocytes leading to the labeling of D-serine as a "gliotransmitter" (Schell et al., 1995, 1997; Wolosker et al., 1999; Panatier et al., 2006). However, more recent studies have 
demonstrated a predominantly neuronal localization (Wolosker et al., 2016). Indeed, germline SRKO mice have been used to validate SR antibody specificity, identifying a preferential expression of SR in neurons in rodent and human brains (Kartvelishvily et al., 2006; Miya et al., 2008; Basu et al., 2009; Ding et al., 2011; Balu et al., 2014, 2018). This neuronal localization of SR was further supported by in situ hybridization (Yoshikawa et al., 2007) and in transgenic mice where the SR coding region was replaced by GFP (Ehmsen et al., 2013). Convincingly, genetic deletion of SR from pyramidal neurons, but not from astrocytes, leads to reduction of brain D-serine concentration (Benneyworth et al., 2012; Ishiwata et al., 2015), and impairment of LTP at CA3-CA1 synapses (Benneyworth et al., 2012; Perez et al., 2017). Furthermore, biochemical evidence from adult rat brain demonstrated the presence of SR in synaptosomes (Balan et al., 2009), and SR has been found to colocalize and coimmunoprecipitate with postsynaptic density protein 95 (PSD-95) in cortical neuronal cultures, supporting a postsynaptic localization of SR (Ma et al., 2014; Lin et al., 2016). However, the functional implications of postsynaptic SR on synaptic transmission are not known.

Here, we demonstrate dendritic and postsynaptic localization of SR and D-serine by immunohistochemistry and electron microscopy in hippocampal CA1 neurons. In addition, using a single-neuron genetic approach in SR conditional $\mathrm{KO}$ mice, we demonstrate a cell-autonomous role for SR in regulating synaptic NMDAR function. Importantly, single-neuron genetic deletion of SR resulted in the elimination of CA3-CA1 LTP at 1 month of age, which was rescued by exogenous $\mathrm{D}$-serine administration. Interestingly, LTP was restored by 2 months with a concomitant upregulation of synaptic GluN2B. This evidence supports a cellautonomous role for postsynaptic neuronal SR in regulating synaptic function and suggests a possible autocrine mode of $\mathrm{D}$-serine action.

\section{Materials and Methods}

Animals

The floxed (fl) SR construct was generated as previously described (Basu et al., 2009; Benneyworth et al., 2012). In this construct, the first coding exon (exon 3 ) is flanked by loxP sites, which results in excision of the intervening sequence on exposure to Cre recombinase. These $\mathrm{Srr}^{\mathrm{fl} / \mathrm{fl}}$ mice are maintained on a C57B/L6J background. WT and constitutive SRKO $\left(\mathrm{Srr}^{-1-}\right)$ mice were produced by breeding SR heterozygous $\left(\mathrm{Srr}^{+/-}\right)$ parents. Mice were grouped housed in polycarbonate cages and maintained on a $12 \mathrm{~h}$ light/dark cycle. Mice of both sexes were used. Animals were given access to food and water ad libitum. The University of California Davis and McLean Hospital Institutional Animal Care and Use Committee approved all animal procedures.

\section{Immunofluorescence}

Postnatal day 16 (P16) and 2-month-old WT or SRKO C57B/L6 mice were deeply anesthetized, briefly intracardially perfused with cold PBS (0.5 м PB, NaCl, pH 7.4), followed by 4\% PFA (Electron Microscopy Sciences) and then in $30 \%$ sucrose $/ \mathrm{PBS}$ at $4^{\circ} \mathrm{C}$. Brains were sectioned at $30 \mu \mathrm{m}$ using a Leica Microsystems SM 2010R Microtome or Microme HM 505E Cryostat and stored in a cryoprotectant solution (ethylene glycol, glycerol, $0.5 \mathrm{M} \mathrm{PB}, \mathrm{NaCl}, \mathrm{KCl}$, in $\mathrm{dH}_{2} 0$ ) at $-20^{\circ} \mathrm{C}$. Free-floating sections were washed 3 times with PBS, then preincubated with permeabilizing agent $0.3 \%$ Triton $\mathrm{X}$ in PBS for $30 \mathrm{~min}$. Sections were incubated in blocking buffer ( $20 \%$ donkey or goat serum, $1 \%$ BSA, $0.1 \%$ glycine, $0.1 \%$ lysine in PBS) for $1 \mathrm{~h}$. This was followed by overnight incubation at $4^{\circ} \mathrm{C}$ with primary antibodies in incubation buffer (5\% donkey or goat serum, $1 \%$ BSA, $0.1 \%$ glycine, and $0.1 \%$ lysine). Primary antibodies used in this study were: mouse anti-SR (BD Biosciences, catalog \#612052), rabbit anti-PSD-95 (Abcam, catalog \#12093), rabbit anti-microtubuleassociated protein 2 (MAP2, Abcam, catalog \#5622). Sections were washed 3 times with PBS, then incubated with the appropriate secondary antibodies in incubation buffer for $1 \mathrm{~h}$. The following isotype-specific secondary antibodies were used: donkey anti-rabbit Alexa-488, donkey anti-mouse Alexa-568, donkey anti-rabbit Alexa-647, goat anti-rabbit Alexa-488, and goat anti-mouse Alexa-568. After secondary antibody incubation, tissue sections were washed 3 times with $1 \times$ PBS. Before mounting on Fisherbrand Superfrost Plus glass microscope slides, freefloating slices were rinsed with water and counterstained using the nuclear maker DAPI. Finally, glass slides were covered using cover glass with Vectashield antifade mounting media (Vectorlabs). Confocal images were acquired using a Leica Microsystems SP8 confocal microscope $(20 \times / 40 \times$ objectives $)$ and $z$-series stack confocal images were taken at fixed intervals using consistent settings.

\section{Electron microscopy}

Two-month-old mice were deeply anesthetized, briefly intracardially perfused with cold PBS ( $0.5 \mathrm{M} \mathrm{PB}, \mathrm{NaCl}, \mathrm{pH} 7.4)$, followed by either $3 \%$ glutaraldehyde, $1 \% \mathrm{PFA}$, and $0.2 \%$ sodium metabisulfite in $0.1 \mathrm{M} \mathrm{PB}, \mathrm{pH}$ 7.4, for D-serine nanogold staining (Balu et al., 2014) or 4\% PFA and $0.5 \%$ glutaraldehyde in $0.1 \mathrm{M} \mathrm{PB}, \mathrm{pH} 7.4$, for SR DAB staining. Brains were postfixed in either $0.002 \% \mathrm{CaCl}_{2}, 0.1 \%$ sucrose, $3 \%$ glutaraldehyde, $1 \%$ PFA in $\mathrm{dH}_{2} 0$ (pH 7.4; D-serine staining) or $4 \%$ PFA, $0.1 \%$ sucrose, $0.5 \%$ glutaraldehyde ( $\mathrm{pH} 7.4 ; \mathrm{SR}$ staining). Brains were washed with $0.1 \mathrm{M}$ PB 3 times for $10 \mathrm{~min}$, and sectioned using a Leica Microsystems VT1200S Vibratome at $40 \mu \mathrm{m}$ and stored in cryoprotectant at $-20^{\circ} \mathrm{C}$.

Nanogold staining. The $1.5 \mathrm{~mm}$ discs were punched out of CA1 region of hippocampal slices; punches were immediately transferred into a 0.1 -mm-deep cavity aluminum platelets (Type A) filled with $20 \%$ BSA as cryoprotectant for high-pressure freezing and covered with a Type B platelet (flat side) (Wohlwend, Sennwald, Switzerland). Samples were rapidly frozen using a Leica Microsystems HPM-100 high-pressure freezer. Frozen samples were transferred in cryo-vials filled with $0.1 \%$ uranyl acetate in anhydrous acetone and placed in a precooled Leica EM-AFS2 machine at $-95^{\circ} \mathrm{C}$. After an hour, the temperature was increased to $-90^{\circ} \mathrm{C}$, and the samples were kept at this temperature for the next $3 \mathrm{~d}$. The temperature was then increased to $-45^{\circ} \mathrm{C}$ for $9 \mathrm{~h}$, followed by three baths of extra-dry acetone for $20 \mathrm{~min}$ each at $-45^{\circ} \mathrm{C}$. Then samples with infiltrated with 10\% Lowicryl HM20 (Electron Microscopy Science, Cat \#14340) in extra-dry acetone at increasing temperature $\left(-45\right.$ to $\left.-25^{\circ} \mathrm{C}\right)$ for $4 \mathrm{hr}$, then increasing Lowicryl HM20 concentration $(25 \%, 50 \%, 75 \%)$ for $4 \mathrm{hr}$ each at $-25^{\circ} \mathrm{C}$, and then four times in $100 \%$ Lowicryl HM20 for $10 \mathrm{hr}$ each at $-25^{\circ} \mathrm{C}$. The HM20 infiltrated samples were flat embedded and polymerized using the UV lamp on the Leica Microsystems AFS-2 machine at $-25^{\circ} \mathrm{C}$ for $48 \mathrm{~h}$, the temperature was increased progressively to $20^{\circ} \mathrm{C}$ for the next $9 \mathrm{~h}$ and held at $20^{\circ} \mathrm{C}$ for the next $4 \mathrm{~d}$. Samples were sectioned at $70 \mathrm{~nm}$ using the Reichert-Jung Ultracut E ultramicrotome, sections were placed on nickel slot grids (Electron Microscopy Sciences, catalog \#G2010-Ni) covered with Formvar support film and immediately followed by immunogold labeling.

Sections were washed with filtered (0.05 M TBS, pH 7.4, with $0.15 \%$ glycine) for $10 \mathrm{~min}$, incubated with filtered $2 \%$ normal goat serum in $0.05 \mathrm{M}$ TBS, pH 7.4, for $10 \mathrm{~min}$, and then incubated with rabbit anti-Dserine antibody (1:750, Abcam, \#6472) with $0.05 \mathrm{~mm}$ L-serine-BSA-glutaraldehyde conjugate in $2 \%$ normal goat serum in $0.05 \mathrm{~m} \mathrm{TBS,} \mathrm{pH} \mathrm{7.4,}$ adjusted from Balu et al. (2014). We previously validated this D-serine IHC protocol using SRKO tissue to demonstrate the necessity of L-serine blocking conjugate inclusion to prevent antibody cross reactivity with L-serine, which is highly expressed in astrocytes (J. H. Yang et al., 2010). Following incubation, sections were washed ( $0.05 \mathrm{~m} \mathrm{TBS}, \mathrm{pH} 7.4) 5$ times for 2 min, incubated in $2 \%$ NGS in $0.05 \mathrm{M} \mathrm{TBS}$, pH 8.2, for $5 \mathrm{~min}$, and then incubated with goat anti-rabbit IgG H\&L (10 nm Gold; 1:20, Abcam, catalog \#39601) in filtered 2\% normal goat serum (0.05 м TBS, $\mathrm{pH}$ 8.2) for $2 \mathrm{~h}$. Sections were washed in $0.05 \mathrm{M}$ TBS, $\mathrm{pH}$ 7.4, 6 times for $2 \mathrm{~min}$, incubated in $2 \%$ glutaraldehyde in $0.05 \mathrm{~m}$ TBS, pH 7.4, for $5 \mathrm{~min}$, washed in $0.05 \mathrm{M}$ TBS, pH 7.4, twice for $2 \mathrm{~min}$, and then in $\mathrm{ddH}_{2} \mathrm{O}_{3}$ times for $2 \mathrm{~min}$. Before being imaged, sections were poststained with filtered uranyl acetate (saturated solution) for $15 \mathrm{~min}$, washed in $\mathrm{ddH}_{2} \mathrm{O}$ by dipping 20 times, and then incubated in Reynold's lead citrate for $7 \mathrm{~min}$. 

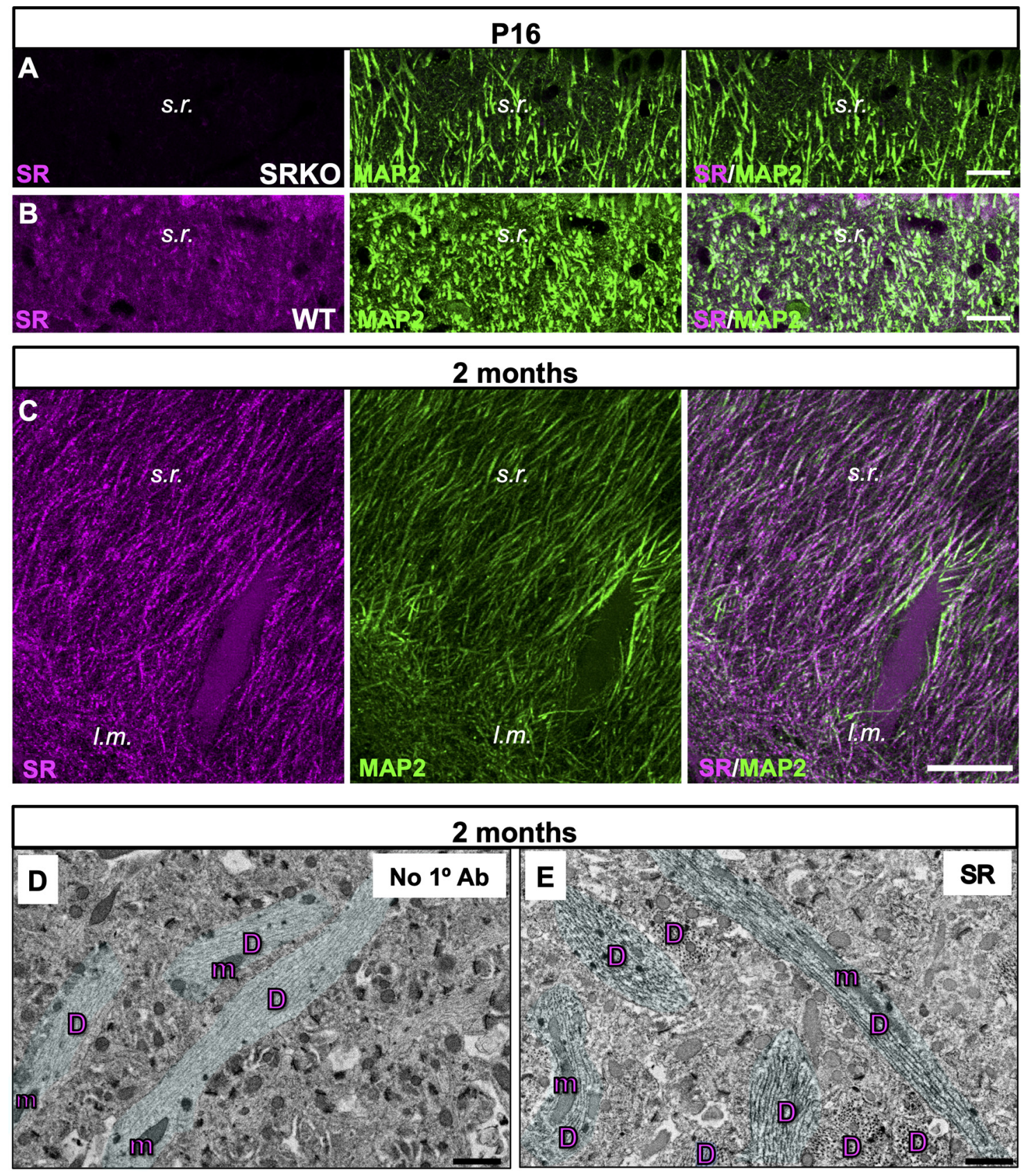

Figure 1. SR is present in the apical dendrites of pyramidal neurons in CA1. $A-C$, Representative confocal images showing colocalization of SR immunofluorescence (magenta) with MAP2 (green) in the apical dendrites of CA1 pyramidal neurons in s.r. at either P16 (A; SRKO; $\boldsymbol{B}$; WT) or 2 months (C; WT). Scale bars, $10 \mu \mathrm{m}$. $\boldsymbol{D}, \boldsymbol{E}$, Transmission electron microscopy (TEM) micrographs showing SR DAB photoreaction product in CA1 apical dendrites at 2 months ( $n=3$ mice; shaded cyan regions). Scale bars, $500 \mathrm{~nm}$. D: dendrite, m: mitochondria, s.r.: stratum radiatum.

Sections were imaged using a JEOL JEM-1200 EX II with a 1k CCD electron microscope (FEI) and recorded using a $2 \mathrm{~K} 2 \mathrm{~K}$ charged-coupled device (CCD) camera, at 1900 magnification (1.12nm pixel size). For large overviews, we acquired montages of overlapping high-magnification images in an automated fashion using the microscope control software SerialEM (Mastronarde, 2005).

$D A B$. Endogenous peroxidases were quenched by incubating sections with $0.3 \% \mathrm{H}_{2} \mathrm{O}_{2}$ in $0.01 \mathrm{M}$ PBS for $15 \mathrm{~min}$. Sections were washed in wash buffer 1 (0.01\% Triton X-100 in $0.01 \mathrm{M}$ PBS) 3 times and then incubated with $0.05 \%$ fresh $\mathrm{NaBH}_{4}$ containing $0.1 \%$ glycine for $30 \mathrm{~min}$ to quench aldehydes. Sections were washed with $0.01 \mathrm{M}$ PBS 3 times and incubated in blocking buffer ( $4 \%$ BSA, 10\% normal goat serum, $0.01 \%$ Triton X-100 in $0.01 \mathrm{~m}$ PBS) for $1 \mathrm{~h}$ at room temperature. Sections were washed once with wash buffer 1 and incubated for $2 \mathrm{~d}$ at $4^{\circ} \mathrm{C}$ with mouse anti-SR antibody (1:1000; BD Biosciences, catalog \#612052). Sections were washed with buffer 1,3 times for $5 \mathrm{~min}$ and incubated in horse anti-mouse IgM-biotinylated (Vector Labs, BA-2020; 1:500) in blocking buffer for $2 \mathrm{~h}$ at room temperature. Sections were washed with buffer 1 . Sections were incubated for $2 \mathrm{~h}$ at room temperature with streptavidinHRP (Invitrogen; catalog \#434323; 1:5000) in buffer 1. Sections were washed twice in $0.1 \mathrm{~m} \mathrm{~PB}$, incubated sections with $\mathrm{DAB}-\mathrm{H}_{2} \mathrm{O}_{2}$ (Vector, catalog \#4105) made in $0.01 \mathrm{M} \mathrm{Na}$ cacodylate for $5 \mathrm{~min}$, and then washed twice with $0.1 \mathrm{M} \mathrm{PB}$. Sections were postfixed in $1 \% \mathrm{OsO}_{4}$ for $30 \mathrm{~min}$, dehydrated in graded ethanol series and extra dry acetone, and flat-embedded in Embed 812 resin. Ultrathin sections $(\sim 80 \mathrm{~nm})$ were collected on Formvar-coated slot grids (Electron Microscopy Sciences, catalog \#G2010-Cu). Some of the sections were imaged without staining and some were poststained with uranyl acetate (saturated solution) and Reynold's lead citrate, before being imaged. Unstained/stained sections were imaged on a JEOL JEM-1200 EX II with an 1k CCD camera, and 

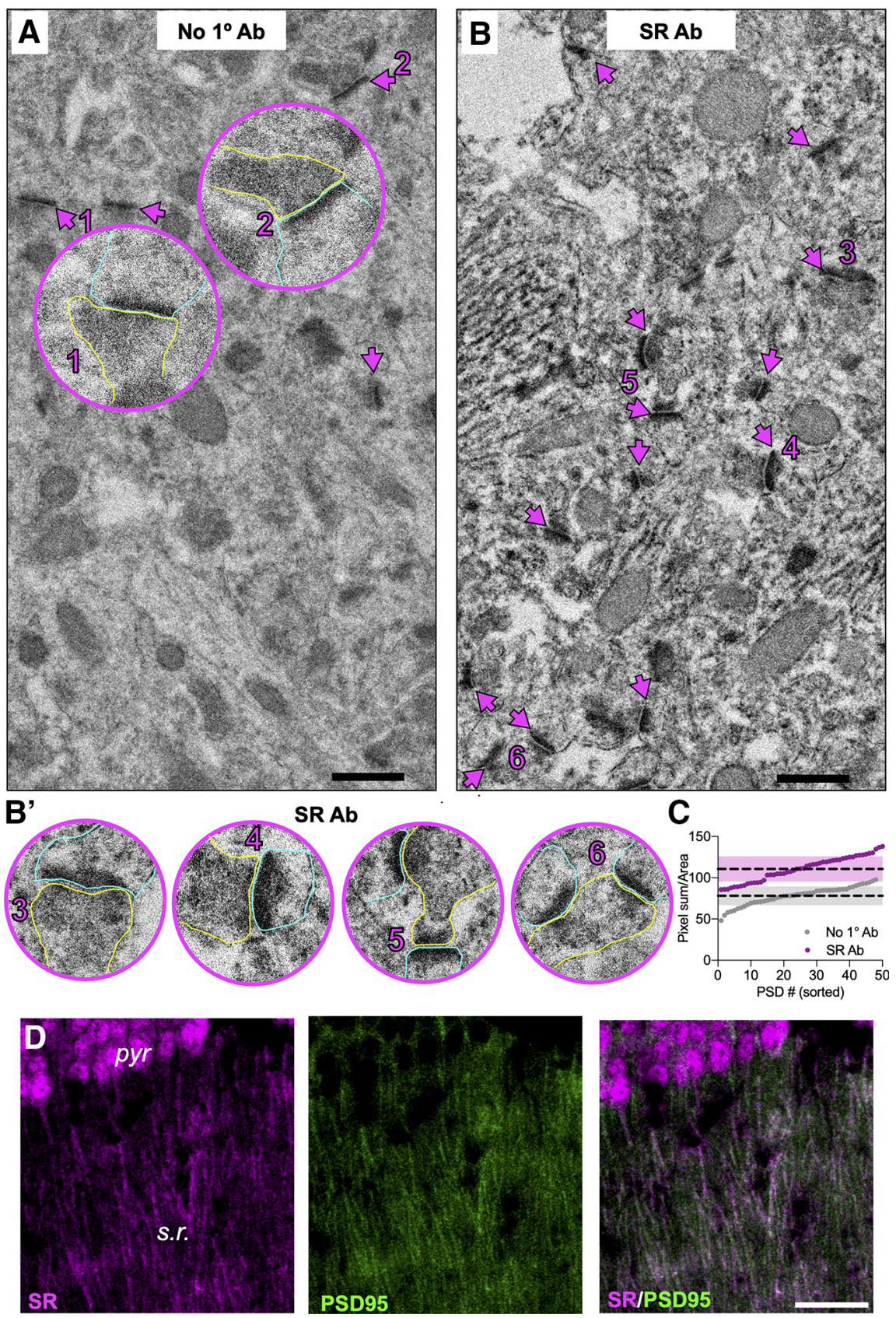

Figure 2. SR is enriched in the PSD of dendritic spines in CA1. $A, B$, Transmission electron microscopy (TEM) micrographs showing SR DAB photoreaction product (arrows) in hippocampal synapses of CA1 s.r. Scale bars, $500 \mathrm{~nm}$. Circle insets in $\boldsymbol{B}^{\prime}$ show enlarged view of presynaptic (yellow outline) and postsynaptic (cyan outline) compartments numbered in $\boldsymbol{B}$. $\boldsymbol{C}$, Intensity of DAB product at individual PSDs as pixel intensity per Rol, sorted to show range. Dashed lines indicate average pixel intensity \pm SD in shaded bars (No. $1^{\circ} \mathrm{Ab}, 78.0 \pm 11.4, n=48$; SR Ab, $110.6 \pm 15.3, n=50 ; n=1$ mouse). D. Representative confocal images of SR immunofluorescence (magneta) showing colocalization with PSD-95 (green) at 2 months. Scale bars, $10 \mu$ m; ( $n=3$ mice). pyr, stratum pyramidale; s.r., stratum radiatum.

on a Tecnai F20 (200 keV) transmission electron microscope (FEI) and recorded using a $2 \mathrm{~K} \times 2 \mathrm{~K}$ charged-coupled device $(\mathrm{CCD})$ camera, at $1900 \times$ magnification (1.12 nm pixel size). For large overviews, we acquired montages of overlapping high-magnification images in an automated fashion using the microscope control software SerialEM (Mastronarde, 2005).

\section{Electrophysiology}

Postnatal viral injection. Neonatal [P0-P1] Srr ${ }^{\mathrm{f} / / \mathrm{fl}}$ mice of both sexes were stereotaxically injected with high-titer rAAV1-Cre:GFP viral stock $\left(\sim 1-5 \times 10^{12} \mathrm{vg} / \mathrm{ml}\right)$ with coordinates targeting CA1 of hippocampus as previously described (Gray et al., 2011). Transduced neurons were identified by nuclear GFP expression. Cre expression was generally limited to the hippocampus within a sparse population of CA1 pyramidal neurons.

Acute slice preparation. Mice older than P30 were anesthetized with isoflurane and transcardially perfused with ice-cold ACSF containing the following (in $\mathrm{mm}$ ): $119 \mathrm{NaCl}, 26.2 \mathrm{NaHCO}_{3}, 11$ glucose, $2.5 \mathrm{KCl}, 1$ $\mathrm{NaH}_{2} \mathrm{PO}_{4}, 2.5 \mathrm{CaCl}_{2}$, and $1.3 \mathrm{MgSO}_{4}$. Modified transverse $300 \mu \mathrm{m}$ slices of dorsal hippocampus were prepared by performing a $\sim 10^{\circ}$ angle blocking cut of the dorsal portion of each cerebral hemisphere (Bischofberger et al., 2006), then mounting the cut side down on a Leica Microsystems VT1200 vibratome in ice-cold ACSF. Slices were incubated in $32^{\circ} \mathrm{C}$ NMDG solution containing the following (in $\mathrm{mm}$ ): 93 NMDG, $93 \mathrm{HCl}, 2.5 \mathrm{KCl}, 1.2 \mathrm{NaH}_{2} \mathrm{PO}_{4}, 30 \mathrm{NaHCO}_{3}, 20$ HEPES, 25 
glucose, 5 sodium ascorbate, 2 thiourea, 3 sodium pyruvate, $10 \mathrm{MgSO}_{4}$, and $0.5 \mathrm{CaCl}_{2}$ (Ting et al., 2018) for $15 \mathrm{~min}$, transferred to room temperature ACSF, and held for at least $1 \mathrm{~h}$ before recording. Mice younger than P30 were anesthetized in isoflurane and decapitated. Brains were rapidly removed and placed in ice-cold sucrose cutting buffer, containing the following (in $\mathrm{mm}$ ): 210 sucrose, $25 \mathrm{NaHCO}_{3}, 2.5 \mathrm{KCl}, 1.25$ $\mathrm{NaH}_{2} \mathrm{PO}_{4}, 7$ glucose, $7 \mathrm{MgCl}_{2}$, and $0.5 \mathrm{CaCl}_{2}$. Slices were cut in sucrose cutting buffer as described above. Slices were recovered for $1 \mathrm{~h}$ in $32^{\circ} \mathrm{C}$ ACSF. All solutions were vigorously perfused with $95 \% \mathrm{O}_{2}$ and $5 \% \mathrm{CO}_{2}$. Slices were transferred to a submersion chamber on an upright Olympus microscope, perfused in room temperature ACSF containing picrotoxin $(0.1$ $\mathrm{mM}$ ), and saturated with $95 \% \mathrm{O}_{2}$ and $5 \% \mathrm{CO}_{2}$. $\mathrm{CA} 1$ neurons were visualized by infrared differential interference contrast microscopy, and $\mathrm{GFP}^{+}$cells were identified by epifluorescence microscopy.

Whole-cell patch clamp. Cells were patched with 3-5 $\mathrm{M} \Omega$ borosilicate pipettes filled with intracellular solution containing the following (in $\mathrm{mm}$ ): 135 cesium methanesulfonate, $8 \mathrm{NaCl}, 10$ HEPES, 0.3 Na-GTP, 4 Mg-ATP, 0.3 EGTA, and 5 QX-314. Series resistance was monitored and not compensated, and cells were discarded if series resistance varied $>25 \%$. All recordings were obtained with a Multiclamp 700B amplifier (Molecular Devices), filtered at $2 \mathrm{kHz}$, and digitized at $10 \mathrm{~Hz}$. All EPSCs were evoked at $0.1 \mathrm{~Hz}$. AMPA receptor EPSCs were recorded at -70 $\mathrm{mV}$. NMDAR-EPSCs were recorded in the presence of $10 \mu \mathrm{M}$ NBQX at $40 \mathrm{mV}$, with the exception of $\mathrm{D}$-serine wash experiments, which were recorded at $-40 \mathrm{mV}$ (Bergeron et al., 1998; Basu et al., 2009). Dual-whole-cell recordings are the average response of $\sim 40$ sweeps, the typical recording length. Paired-pulse ratio (PPR) was performed with two sequential EPSCs at a $50 \mathrm{~ms}$ interval. LTP was induced by depolarization to $0 \mathrm{mV}$ paired with $1 \mathrm{~Hz}$ stimulation for $90 \mathrm{~s}$. Ro25-6981 (Ro25) and D-serine wash experiments recorded NMDAR-EPSCs by coming to a

steady $5 \mathrm{~min}$ baseline before proceeding with wash. EPSC amplitude was determined by measuring the peak of the response compared with prestimulation baseline. All summary amplitude graphs after a time course experiment average the last $5 \mathrm{~min}$ of data compared with baseline. EPSC charge transfer was determined by measuring the area of the response compared with prestimulation baseline. EPSC decay time was measured as the time between EPSC peak amplitude and 63\% decay from the peak. Analysis was performed with the Clampex software suite (Molecular Devices).

\section{Experimental design and statistical analysis}

All data represent the mean $\pm \mathrm{SEM} ; n=$ number of neurons or pairs of neurons. In electrophysiology experiments, two or three data points were typically acquired per mouse. Experiments include both males and females. Data were analyzed using Clampfit 10.4 (Molecular Devices) and Prism 8 software (GraphPad). Data were analyzed using an unpaired $t$ test for LTP and exogenous D-serine wash recordings, a ratio-paired $t$ test for paired amplitude data, and paired $t$ test for decay kinetics. In all cases, $p<0.05$ was considered significant. For transmission electron microscopy (TEM), micrographs were visualized on IMOD software (Kremer et al., 1996), clearly defined synapses (preneurons and postneurons) were identified, and all postsynaptic neurons were manually counted for nanogold-labeled D-serine. No D-serine was detected in the presynaptic neuron. For SR quantification, in ImageJ, an ROI was drawn at $\sim 50$ synapses for both SR-labeled and control (no antibody) sections; pixel intensity was quantified per ROI for each synapse.

\section{Results}

\section{Postsynaptic localization of SR and}

D-serine

Biochemical evidence from adult rat brain demonstrated the presence of SR in synaptic compartments (Balan et al., 2009), while in primary mouse neuronal cortical cultures, SR and Dserine colocalize with PSD-95 and NMDARs (GluN1) in postsynaptic glutamatergic synapses, but not in presynaptic terminals (Ma et al., 2014; Lin et al., 2016). Furthermore, SR expression is developmentally regulated in the mouse brain, with low levels early postnatally and peaking $\sim$ P28 (Miya et al., 2008; Basu et al., 2009). In the CA1 subfield of dorsal hippocampus at P16 (Fig. 1A,B), a low and diffuse expression of SR was detected in apical dendrites of stratum radiatum ( $s$. $r$.), and no staining was seen in SRKO mice. By 2 months of age, there is robust SR expression throughout CA1, including high levels in apical dendrites as demonstrated by colocalization with MAP2 (Fig. 1C). Using immuno-electron microscopy (EM), we show that SR is present in CA1 apical 

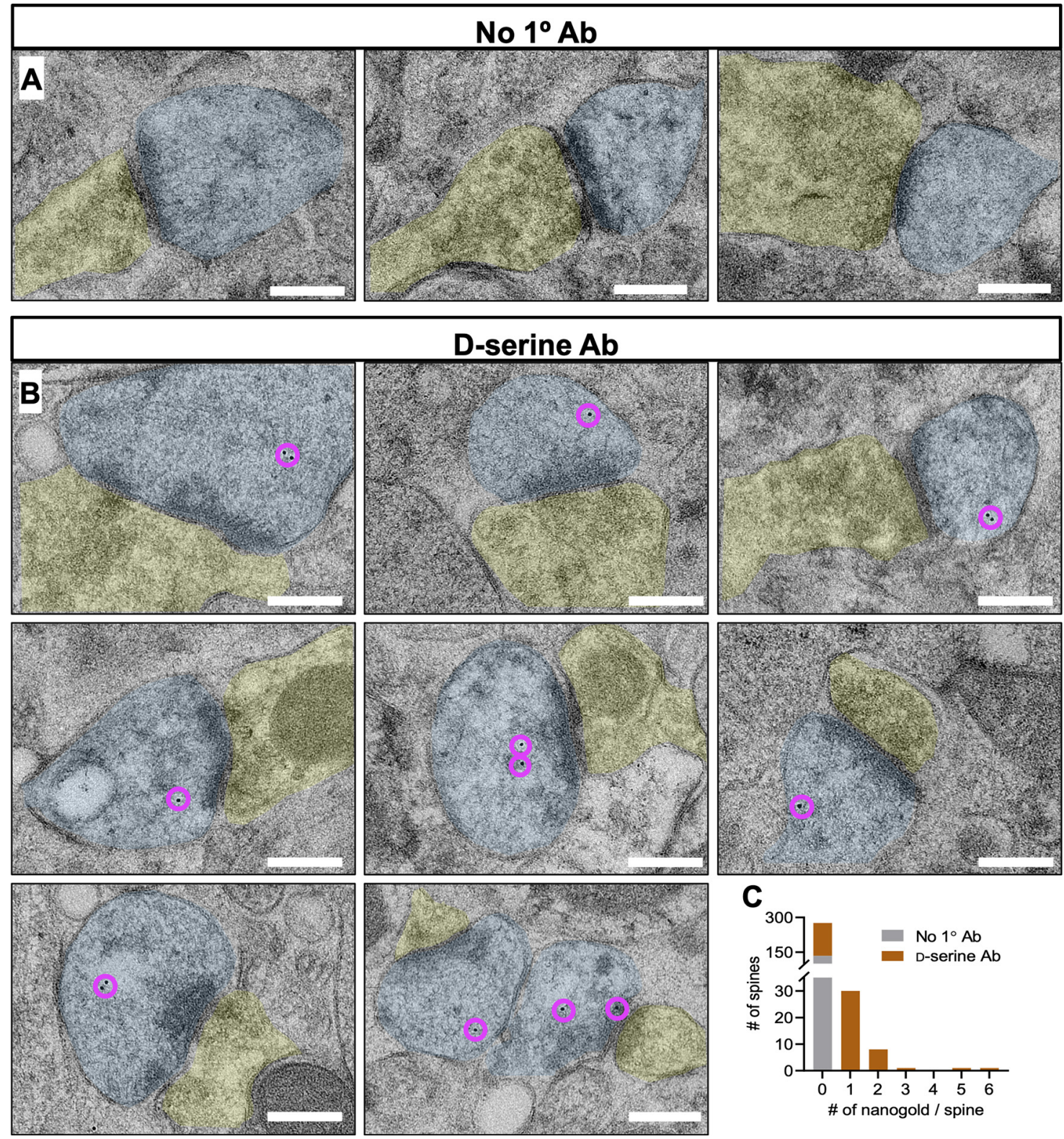

Figure 4. D-serine is present in dendritic spines in CA1. A, B, Transmission electron microscopy (TEM) micrographs showing D-serine nanogold particles (magenta circles) in dendritic spines in CA1 s.r. at 2 months of age (yellow shading: presynaptic compartments; cyan shading: postsynaptic compartments). C, Histogram showing the number of D-serine nanogold particles in dendritic spines ( $n=1$ mouse; $130-300$ dendritic spines). Scale bar, $100 \mathrm{~nm}$.

dendrites of s.r., with no SR immunoreactivity in control sections, in which only the primary SR antibody was omitted (Fig. 1D,E).

We also examined whether SR was localized to postsynaptic compartments in s.r. of CA1. We found a more intense $\mathrm{DAB}$ product as determined by the pixel intensity per ROI at PSDs in SR-antibody-stained sections compared with control sections with no primary antibody, demonstrating the presence of SR in dendritic spines (Fig. $2 A-C$; average pixel intensity/area; No $1^{\circ}$ $\mathrm{Ab}, 78.0 \pm 11.4$ [SD], $n=48$; SR Ab, $110.6 \pm 15.3$ [SD], $n=50$ ). However, we did not detect SR immunoreactivity in presynaptic compartments (Fig. 2B). Using dual-antigen immunofluorescence, we also demonstrate colocalization of SR with the PSD marker, PSD-95 in CA1 (Fig. 2D).

Since we detected the enzyme SR in dendrites and spines, we next examined whether the NMDAR coagonist D-serine is also localized to these compartments. Using immuno-EM and a D- serine immunostaining protocol that we previously validated using SRKO mice (Balu et al., 2014), we observed high numbers of nanogold particles in CA1 s.r. dendrites, while we did not detect any dendritic nanogold particle binding in control sections that omitted only D-serine primary antibody (Fig. $3 A-C$ ). Finally, we detected nanogold particles postsynaptically in dendritic spines in CA1, but not in presynaptic compartments or in control sections that were not incubated with the D-serine primary antibody (Fig. 4A-C).

\section{Single-neuron genetic deletion of SR does not alter synaptic function in P16-P21 CA1}

To examine the physiological function of postsynaptic SR, we used a single-neuron genetic approach in SR conditional KO mice. Here, SR was removed in a sparse subset of CA1 pyramidal neurons by P0 stereotaxic injection of adeno-associated virus, serotype 1 expressing a Cre recombinase GFP fusion protein 
(AAV1-Cre:GFP) into floxed SR $\left(\mathrm{Srr}^{\mathrm{fl} / \mathrm{fl}}\right)$ mice (Fig. 5A). This mosaic transduction allows for simultaneous whole-cell recordings from Cre-expressing $\left(\mathrm{Cre}^{+}\right)$and neighboring untransduced neurons (control) (Fig. $5 B$ ), providing a rigorous comparison of the cell-autonomous effects of SR deletion while controlling for presynaptic input (Gray et al., 2011).

Glycine is thought to be the primary synaptic NMDAR coagonist at early developmental stages before being gradually supplanted by D-serine around the third postnatal week in CA1 (Le Bail et al., 2015). Therefore, we first assessed the contribution of postsynaptic SR to synaptic physiology at P16-P21. In P16-P21 mice, we found no difference in the NMDAREPSC amplitudes between control and $\mathrm{Cre}^{+}$neurons (Fig. 5C; control: $131.7 \pm$ $25.9 \mathrm{pA}, n=11 ; \mathrm{Cre}^{+}: 114.0 \pm 24.4 \mathrm{pA}$, $n=11 ; t_{(10)}=1.625, p=0.1351$, ratio paired $t$ test). Decay kinetics of NMDAR-EPSCs, measured as the time between the EPSC peak and $63 \%$ decay, were also unchanged (Fig. $5 D$; control: $170.0 \pm 7.5 \mathrm{~ms}, n=10$; $\mathrm{Cre}^{+}: 173.1 \pm 10.8 \mathrm{~ms}, n=10 ; t_{(9)}=0.2197$, $p=0.8310$, paired $t$ test). We also recorded AMPAR-EPSCs from P16-P21 mice in a pairwise manner and likewise found no change in AMPAR-EPSCs (Fig. $5 E$; control: $85.9 \pm 22.3 \mathrm{pA}, n=9$; $\mathrm{Cre}^{+}: 91.0 \pm$ $20.2 \mathrm{pA}, n=9 ; t_{(8)}=0.778, p=0.459$, ratio paired $t$ test). Finally, we recorded pairedpulse ratios (PPRs) with a $50 \mathrm{~ms}$ interval from control and $\mathrm{Cre}^{+}$neurons and found no change in PPR (Fig. $5 F ; 2.21 \pm 0.28$, $n=4 ; \mathrm{Cre}^{+}: 1.94 \pm 0.21, n=4 ; t_{(6)}=0.7694$, $p=0.4708, t$ test). As expected, postsynaptic SR deletion has no observed effect on synaptic function in P16-P21 CA1 consistent with glycine being the primary synaptic coagonist at this time point.

\section{Single-neuron genetic deletion of SR reduces NMDAR-EPSCs in P45-P70 CA1}

Next, we performed recordings at $\sim 2$ months of age when D-serine is clearly the primary synaptic NMDAR coagonist (Papouin et al., 2012; Le Bail et al., 2015). In P45-P70 mice, we found that postsynaptic SR deletion decreased NMDAR-EPSCs in $\mathrm{Cre}^{+}$ neurons (Fig. 6 A; control: $144.1 \pm 18.9$ pA, $n=19$; $\mathrm{Cre}^{+}: 87.6 \pm$ $11.7 \mathrm{pA}, n=19 ; t_{(18)}=3.689, p=0.0017$, ratio paired $t$ test). Importantly, AMPAR-EPSCs were unchanged, indicating that the effect was specific to NMDARs (Fig. $6 B$; control: $111.8 \pm$ $19.0 \mathrm{pA}, n=14 ; \mathrm{Cre}^{+}: 85.4 \pm 15.7 \mathrm{pA}, n=14 ; t_{(13)}=1.936$, $p=0.0749$, ratio paired $t$ test). PPR was also unchanged (Fig. $6 C$; control: $1.83 \pm 0.15, n=9 ; \mathrm{Cre}^{+}: 1.70 \pm 0.22, n=9 ; t_{(16)}=0.4649$, $p=0.6483, t$ test), suggesting that the NMDAR-EPSC decrease was postsynaptic in origin. Previous studies have demonstrated that acute removal of NMDAR coagonists impairs synaptic plasticity (Papouin et al., 2012; Le Bail et al., 2015) and that germline and neuron-specific SR deletion reduces LTP (Basu et al., 2009; Benneyworth et al., 2012; Balu et al., 2013; Perez et al., 2017).
B

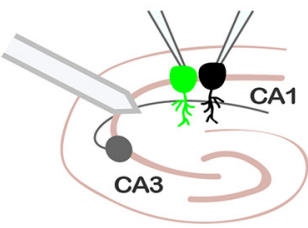

D
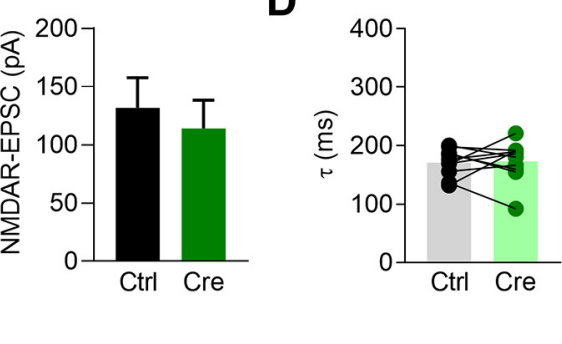

$\mathbf{F}$
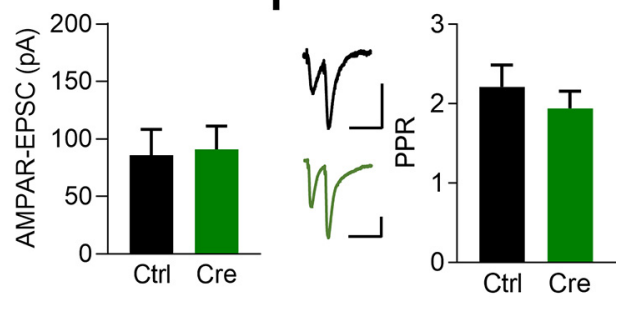

Figure 5. No effects at P16-21 following single-neuron SR deletion. $\boldsymbol{A}$, Representative image of the sparse transduction paired recordings in $\boldsymbol{C}\left(t_{(9)}=0.2197, p=0.8310\right.$, paired $t$ test). $\boldsymbol{E}$, Scatterplot of paired neuronal recordings of P16-21 AMPAR-EPSCs (open circles) and averaged pair (solid circle). Sample trace bars indicate $200 \mathrm{~ms}, 30 \mathrm{pA}$. Average AMPAR$p=0.4590$, ratio paired $t$ test). $\boldsymbol{F}$, Average PPR for control $(2.21 \pm 0.28, n=4)$ and Cre:GFP ${ }^{+}$neurons $(1.94 \pm 0.21$, $n=4 ; t_{(6)}=0.7694, p=0.4708, t$ test). Sample trace bars indicate $100 \mathrm{~ms}, 30 \mathrm{pA}$. Data represent mean \pm SEM.

Therefore, we assessed the effect of single-cell postsynaptic deletion of SR on LTP. Surprisingly, we found that LTP was unchanged in $\mathrm{Cre}^{+}$neurons (Fig. $6 D$; control: $193.9 \pm 22.1 \%$, $n=12$; Cre $^{+}: 196.6 \pm 15.1 \%, n=12 ; t_{(22)}=0.09961, p=0.9216$, $t$ test).

\section{Single-neuron genetic deletion of SR upregulates GluN2B in P45-P70 CA1}

We next sought to understand the discrepancy between the reduced NMDAR-EPSC amplitude and, in contrast to previous studies, the lack of effect on LTP (Basu et al., 2009; Benneyworth et al., 2012; Balu et al., 2013; Perez et al., 2017). We hypothesized that the reduced NMDAR-EPSC amplitude might be because of a decreased synaptic coagonist concentration and thus less occupancy of the NMDAR coagonist sites. To test this, we washed a saturating concentration of exogenous D-serine onto slices while recording from control and $\mathrm{Cre}^{+}$neurons. If synaptic NMDARs had reduced coagonist saturation in $\mathrm{Cre}^{+}$relative to control cells, exogenous D-serine would be predicted to cause a greater enhancement of the NMDAR-EPSC amplitude in the Cre ${ }^{+}$cells. However, we found that there was no significant difference in the potentiation of $\mathrm{Cre}^{+}$and control cells in response to $100 \mu \mathrm{M}$ D-serine (Fig. $7 A$; control: $125.6 \pm 4.1 \%, n=14$; $\mathrm{Cre}^{+}: 117.4 \pm$ $14.4 \%, n=7 ; t_{(19)}=0.7147, p=0.4835, t$ test $)$. 

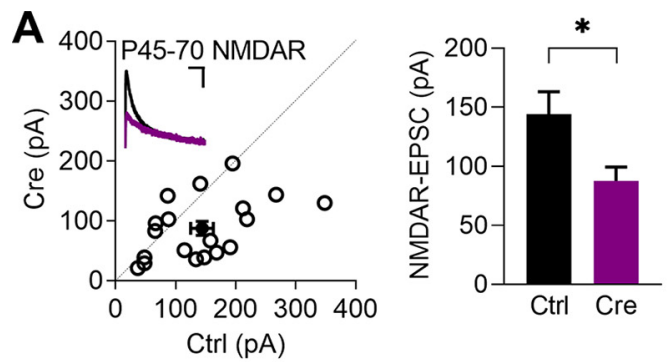

B
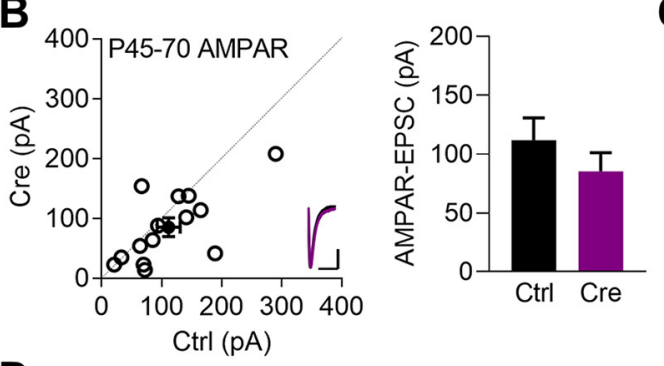

C
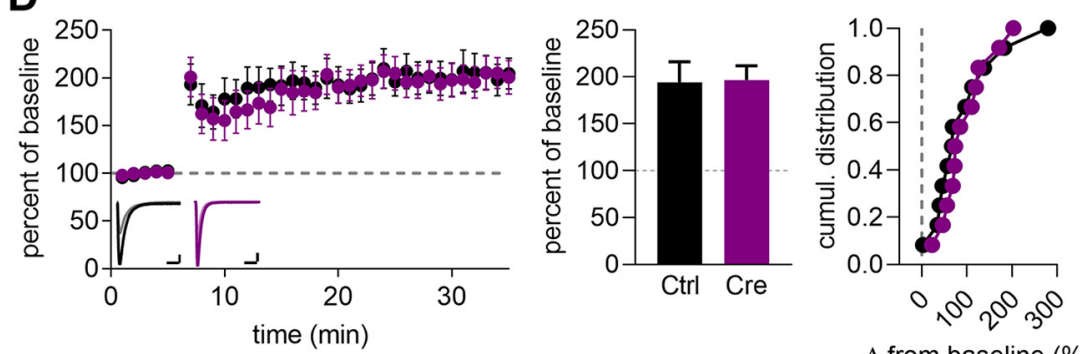

$\Delta$ from baseline (\%)

Figure 6. Reduced NMDAR-EPSCS at P45-P70 following single-neuron SR deletion. $A$, Scatterplot of paired neuronal recordings of P45-P70 NMDAR-EPSCs (open circles) and averaged pair (solid circle). Sample trace bars indicate $200 \mathrm{~ms}, 30 \mathrm{pA}$. Average NMDAR-EPSC amplitudes for control $(144.1 \pm 18.9 \mathrm{pA}, n=19)$ and Cre:GFP $^{+}$neurons $(87.6 \pm 11.7 \mathrm{pA}, n=19$; $t_{(18)}=3.689, p=0.0017$, ratio paired $t$ test). $B$, Scatterplot of paired neuronal recordings of P45-P70 AMPAR-EPSCs (open circles) and averaged pair SEM (solid circle). Sample trace bars indicate $200 \mathrm{~ms}, 30 \mathrm{pA}$. Average AMPAR-EPSC amplitudes for control $(111.8 \pm 19.0 \mathrm{pA}, n=14)$ and Cre:GFP ${ }^{+}$neurons $\left(85.4 \pm 15.7 \mathrm{pA}, n=14 ; t_{(13)}=1.936, p=0.0749\right.$, ratio paired $t$ test). C, Average PPR for control $(1.83 \pm 0.15, n=9)$ and Cre:GFP ${ }^{+}$neurons $\left(1.70 \pm 0.22, n=9 ; t_{(16)}=0.4649, p=0.6483, t\right.$ test). Sample trace bars indicate $100 \mathrm{~ms}, 30 \mathrm{pA}$. D. Left, averaged whole-cell LTP experiments and representative traces $(50 \mathrm{~ms}$, $30 \mathrm{pA})$. Middle, summary of average percentage potentiation relative to baseline; control neurons ( $193.9 \pm 22.1 \%, n=12$ ), Cre:GFP ${ }^{+}$neurons (196.6 $\pm 15.1 \%, n=12 ; t_{(22)}=0.09,961, p=0.9216, t$ test). Right, cumulative distribution of experiments. Data represent mean $\pm \mathrm{SEM}, * p<0.05$.

Interestingly, the decay kinetics of NMDAR-EPSCs were found to be significantly longer in $\mathrm{Cre}^{+}$neurons (Fig. $7 B$; control: $191.1 \pm 12.1 \mathrm{~ms}, \quad n=19 ; \mathrm{Cre}^{+}: 288.6 \pm 30.6 \mathrm{~ms}, \quad n=19$; $t_{(18)}=3.040, p=0.0070$, paired $t$ test). Since prolonged decay of synaptic NMDAR-EPSCs likely indicates an increased proportion of the GluN2B subunit, we tested this pharmacologically with the GluN2B-selective inhibitor Ro25-6981 (Ro25) (Fischer et al., 1997). We found $\mathrm{Cre}^{+}$neurons were significantly more sensitive than control neurons to $5 \mu \mathrm{M}$ Ro25 (Fig. 7C; control: $24.8 \pm 8.7 \%, n=6 ; \mathrm{Cre}^{+}: 61.2 \pm 14.5 \%, n=4 ; t_{(8)}=2.340, p=$ $0.0474, t$ test), demonstrating an increase in the synaptic GluN2B/ GluN2A ratio.

GluN2B-containing NMDARs have lower peak open probability compared with GluN2A-containing NMDARs (N. Chen et al., 1999; Erreger et al., 2005; Gray et al., 2011), although because their single-channel conductances are identical (Stern et al., 1992), a reduction in the macroscopic EPSC amplitude could represent similar numbers of synaptic NMDARs. Indeed, the combination of reduced peak amplitude with the prolonged decay kinetics resulted in no significant change in charge transfer of $\mathrm{Cre}^{+}$neurons (Fig. 7D; control: $40.2 \pm 5.4$ pC, $n=19$; $\mathrm{Cre}^{+}$: $32.3 \pm 3.9 \mathrm{pC}, n=19 ; t_{(18)}=1.518, p=0.1464$, paired $t$ test) consistent with a similar overall number of synaptic NMDARs. Overall, this increase in the GluN2B/GluN2A ratio may represent a homeostatic mechanism to maintain synaptic plasticity.

\section{Single-neuron genetic deletion of SR impairs LTP in P23-P39 CA1}

Since the normal LTP in P45-P70 mice might be because of homeostatic increases in GluN2B in the chronic absence of SR, we next examined an intermediate time point when D-serine is expected to be the primary synaptic coagonist (Le Bail et al., 2015), but compensatory changes may not have yet occurred. Examining mice from the fourth to fifth week of life (P23-P39), we found that the NMDAR-EPSCs and their decay kinetics were unchanged in $\mathrm{Cre}^{+}$ neurons (NMDAR-EPSCs, Fig. 8A; control: $91.7 \pm 27.7 \mathrm{pA}, n=9$; $\mathrm{Cre}^{+}: 140.8 \pm$ $26.3 \mathrm{pA}, n=9 ; t_{(8)}=1.879, p=0.0970$, ratio paired $t$ test; decay, Fig. $8 B$; control: $200.8 \pm 19.4 \mathrm{~ms}, n=7 ; \mathrm{Cre}^{+}: 268.3 \pm$ $60.4 \mathrm{~ms}, n=7 ; t_{(6)}=1.510, p=0.1818$, paired $t$ test). Similar to other time points, AMPAR-EPSCs (Fig. 8C; $60.8 \pm 12.7 \mathrm{pA}$, $n=11 ; \mathrm{Cre}^{+}: 73.4 \pm 10.4 \mathrm{pA}, n=11$; $t_{(10)}=1.724, p=0.1155$, ratio paired $t$ test) and PPR (Fig. $8 D$; control: $2.06 \pm 0.21$, $n=5 ; \mathrm{Cre}^{+}: 2.05 \pm 0.12 ; t_{(8)}=0.01663$, $p=0.9871, t$ test) were unchanged. Interestingly, LTP was completely eliminated in $\mathrm{Cre}^{+}$neurons at P23-P39 and restored by exogenous $\mathrm{D}$-serine applied until the end of the induction period (Fig. $8 E$; control: $151.9 \pm 10.3 \%, n=8$; $\mathrm{Cre}^{+}$: $100.2 \pm 6.1 \%, n=6$; $\mathrm{Cre}^{+}$with D-serine: $164.8 \pm 15.3 \%, n=8$; control to $\mathrm{Cre}^{+}$: $t_{(12)}=3.955, p=0.0019, t$ test; control to $\mathrm{Cre}^{+}$with D-serine: $t_{(14)}=0.7032, p=$ $0.4934, t$ test), demonstrating that neuronal SR cell-autonomously regulates NMDAR function and synaptic plasticity in CA1 pyramidal cells.

\section{Discussion}

Despite the recognized importance of D-serine in NMDAR function and synaptic plasticity, our understanding of the regulation of D-serine synthesis, release, and degradation remains quite limited. Indeed, even the cellular source of D-serine has been contested (Wolosker et al., 2016, 2017; Papouin et al., 2017). Early studies suggested that D-serine is exclusively synthesized and released by astrocytes (Schell et al., 1995, 1997; Wolosker et al., 1999), leading to the classification of D-serine as a gliotransmitter (Wolosker et al., 2002; Miller, 2004; Panatier et al., 2006). More recent studies, using the SR KO mice as controls, have strongly supported a predominantly neuronal localization (for review, see Wolosker et al., 2016). In this study, we demonstrate, for the first time, a cell-autonomous role for neuronal SR in regulating synaptic NMDAR function. Specifically, we find that single-neuron deletion of SR impairs LTP, although LTP is restored later with a concomitant 
A
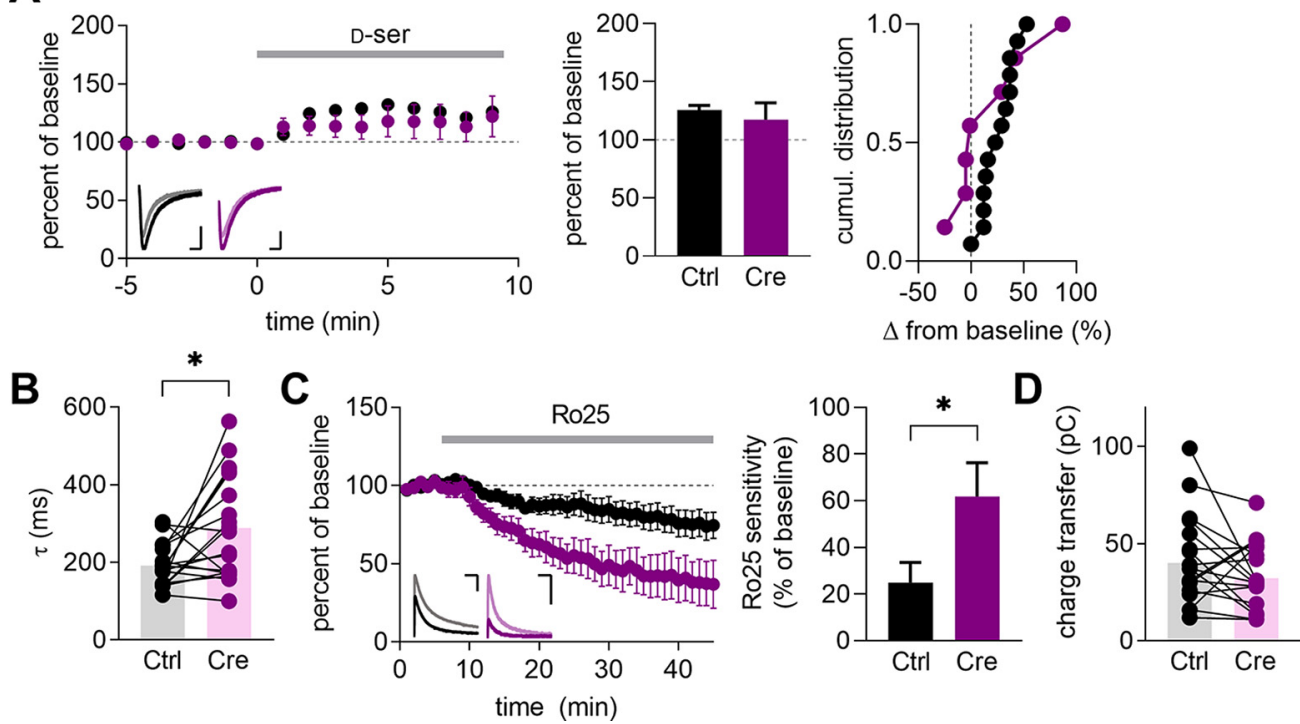

Figure 7. Single-neuron SR deletion increases synaptic GluN2B. A, Averaged whole-cell D-serine wash experiments and representative traces ( $50 \mathrm{~ms}$, $30 \mathrm{pA}$ ). Summary of average percentage potentiation relative to baseline; control neurons (125.6 $\pm 4.1 \%, n=14)$, Cre:GFP ${ }^{+}$neurons $\left(117.4 \pm 14.4 \%, n=7 ; t_{(19)}=0.7147, p=0.4835, t\right.$ test). Cumulative distribution of experiments. $\boldsymbol{B}$, Average decay kinetics of NMDAR-EPSCs for control $(191.1 \pm 12.1 \mathrm{~ms}, n=19)$ and Cre:GFP ${ }^{+}$neurons $(288.6 \pm 30.6 \mathrm{~ms}, n=19)$ from paired recordings in Figure $6 A\left(t_{(18)}=3.040\right.$, $p=0.0070$, paired $t$ test). C, Averaged whole-cell Ro25 wash experiments and representative traces (200 ms, $50 \mathrm{pA})$. Summary of average percentage of current sensitive to Ro25 wash; control neurons $(24.8 \pm 8.7 \%, n=6)$, Cre:GFP ${ }^{+}$neurons $\left(61.2 \pm 14.5 \%, n=4 ; t_{(8)}=2.340, p=0.0474, t\right.$ test). $\boldsymbol{D}$, Average charge transfer of NMDAR-EPSCs for Control (40.2 $\left.\pm 5.4 \mathrm{pC}, n=19\right)$ and Cre:GFP ${ }^{+}$neurons $(32.3 \pm 3.9 \mathrm{pC}, n=19)$ from paired recordings in Figure $6 A\left(t_{(18)}=1.518, p=0.1464\right.$, paired $t$ test). Data represent mean \pm SEM, $* p<0.05$.

upregulation of GluN2B. Furthermore, in agreement with previous studies in cultured neurons (Ma et al., 2014; Lin et al., 2016), we found that SR localizes to the apical dendrites and the PSD in situ in hippocampal CA1 pyramidal neurons. We have also identified D-serine in dendrites and postsynaptic compartments by immunogold EM. Together, these results provide strong evidence for the neuronal localization and cell-autonomous function of SR in the intact hippocampus. In addition, these findings together suggest a possible autocrine mode of $\mathrm{D}$-serine action at synapses.

\section{Regulation of LTP by postsynaptic SR}

We demonstrate that single-neuron SR deletion cell-autonomously impairs LTP in P23-P39 mice. Deficits in neuronal D-serine have been repeatedly shown to reduce LTP. Germline SRKO mice show reduced LTP in CA1 (Basu et al., 2009; Balu et al., 2016; Neame et al., 2019), dentate gyrus (Balu et al., 2013), and lateral amygdala ( $\mathrm{Li}$ et al., 2013). Furthermore, neuron-specific SRKO mice show reduced LTP while astrocyte-specific SRKO mice have normal LTP (Benneyworth et al., 2012; Perez et al., 2017). Similarly, acute enzymatic depletion of D-serine reduces the magnitude of LTP in CA1 (Y. Yang et al., 2003; Papouin et al., 2012; Rosenberg et al., 2013; Le Bail et al., 2015), visual cortex (Meunier et al., 2016), nucleus accumbens (Curcio et al., 2013), and lateral amygdala (Li et al., 2013). Together, these studies suggest that neuronally derived D-serine is crucial for synaptic plasticity. Additionally, the cell-autonomous loss of LTP, and rescue by exogenous $\mathrm{D}$-serine, seen here suggests a possible autocrine mode of D-serine action (discussed below). Surprisingly, this loss of LTP occurred without a reduction in the amplitude of the NMDAR-EPSCs, arguing that baseline coagonist occupancy is not significantly altered, perhaps through compensation by glycine, or through D-serine diffusing from neighboring neurons. However, during plasticity, higher concentrations of coagonist may be required. Indeed, coagonist occupancy of synaptic NMDARs can be altered by activity (Panatier et al., 2006; Li et al., 2009), and glutamate binding reduces the affinity of the NMDAR glycine site up to seven-fold (Mayer et al., 1989; Lester et al., 1993; Cummings and Popescu, 2015), suggesting that additional coagonist release might be needed during plasticity, especially during high-frequency induction protocols not tested in this study.

Interestingly, we found that LTP was restored by P45, possibly through a homeostatic process. This restoration of LTP was associated with an upregulation of synaptic GluN2B. Indeed, a prolongation of the NMDAR-EPSC decay kinetics has been previously reported in the germline SRKO mice (Basu et al., 2009), and GluN2B is known to promote LTP through its unique array of c-tail interacting proteins (Foster et al., 2010). Importantly, the enhancement of GluN2B subunits in CA1 could directly compensate for a lack of D-serine. GluN2A and GluN2B allosterically regulate coagonist potency at the GluN1 glycine binding site (Priestley et al., 1995; Madry et al., 2007; P. E. Chen et al., 2008; Maolanon et al., 2017) with a two- to five-fold higher potency of coagonists at GluN2B-containing NMDARs. Therefore, enhancement of GluN2B could compensate for a loss of D-serine given a smaller but stable pool of synaptic glycine. Indeed, this increase in GluN2B could explain the lack of NMDAR saturation changes in the P45-P70 mice. Other groups using the SRKO or the broad neuronal SR deletion, however, did not observe this restoration of LTP (Basu et al., 2009; Balu et al., 2016; Perez et al., 2017; Neame et al., 2019). Perhaps in the single-neuron SR deletion there is some degree of $\mathrm{D}$-serine spillover from neighboring neurons that is sufficient to fully activate the higher-affinity GluN2B-containing NMDARs and restore LTP, whereas when SR is deleted from all neurons, this spillover is eliminated.

The increase in synaptic GluN2B, however, might solely be an associated finding. One possibility is that NMDAR synaptic stability is regulated by coagonist composition in a subunit-specific manner. Indeed, coagonist binding primes NMDARs for internalization and recycling (Nong et al., 2003), and D-serine administration onto dissociated cortical cultures increases the 
A

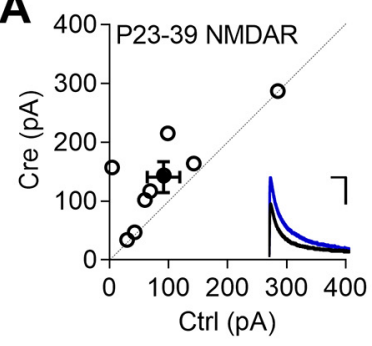

C

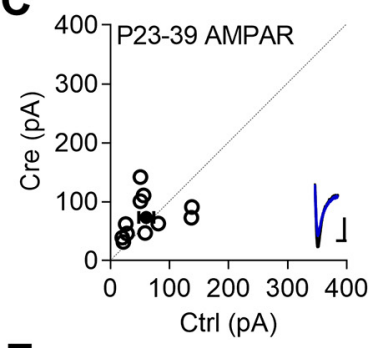

E

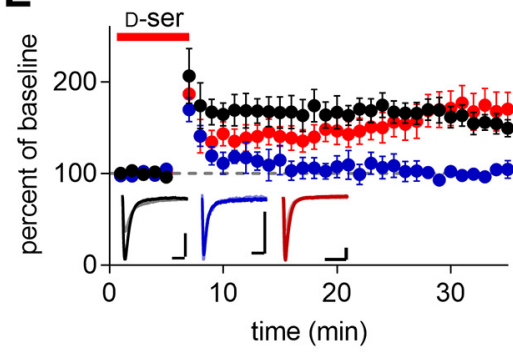

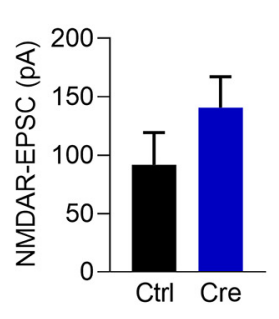

B

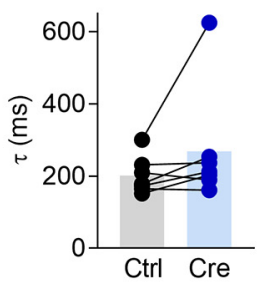

D

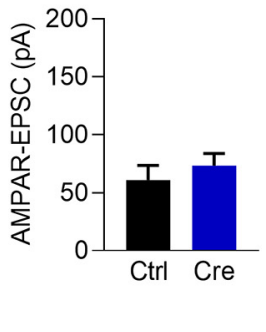

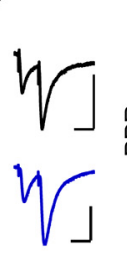

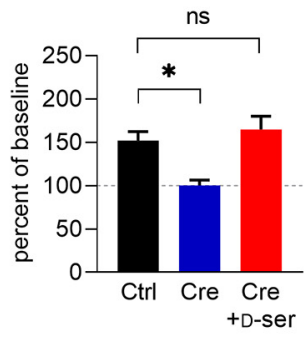

Figure 8. Loss of LTP at P23-P39 following single-neuron SR deletion. A, Scatterplot of paired neuronal recordings of P23-P39 NMDAR-EPSCs (open circles) and averaged pair (solid circle). Sample trace bars indicate $200 \mathrm{~ms}$, $30 \mathrm{pA}$. Average NMDAR-EPSC amplitudes for control $(91.7 \pm 27.7 \mathrm{pA}, n=9)$ and Cre:GFP ${ }^{+}$neurons $\left(140.8 \pm 26.3 \mathrm{pA} ; t_{(8)}=1.879\right.$, $p=0.0970$, ratio paired $t$ test). $\boldsymbol{B}$, Average decay kinetics of NMDAR-EPSCs for control $(200.8 \pm 19.4 \mathrm{~ms}, n=7)$ and (re: $\mathrm{GFP}^{+}$neurons (268.3 $\pm 60.4 \mathrm{~ms}, n=7$ ) from paired recordings in $\boldsymbol{A}\left(t_{(6)}=1.510, p=0.1818\right.$, paired $t$ test). C, Scatterplot of paired neuronal recordings of P23-P39 AMPAR-EPSCs (open circles) and averaged pair (solid circle). Sample trace bars indicate $200 \mathrm{~ms}, 30 \mathrm{pA}$. Average AMPAR-EPSC amplitudes for control $(60.8 \pm 12.7 \mathrm{pA}, n=11)$ and Cre:GFP $^{+}$neurons $\left(73.4 \pm 10.4 \mathrm{pA}, n=11 ; t_{(10)}=1.724, p=0.1155\right.$, ratio paired $t$ test). $\boldsymbol{D}$, Average PPR for control $(2.06 \pm 0.21, n=5)$ and Cre:GFP ${ }^{+}$neurons $\left(2.05 \pm 0.12 ; t_{(8)}=0.01663, p=0.9871, t\right.$ test). Sample trace bars indicate $100 \mathrm{~ms}, 30 \mathrm{pA}$. $E$, Left, averaged whole-cell LTP experiments and representative traces of control neurons (black), (re:GFP ${ }^{+}$neurons (blue), and Cre:GFP ${ }^{+}$neurons with $100 \mu \mathrm{m}$ exogenous D-serine administered through the end of the induction (red) $(50 \mathrm{~ms}, 30 \mathrm{pA})$. Middle, summary of average percentage potentiation relative to baseline; control neurons ( $151.9 \pm 10.3 \%, n=8)$, Cre: $\mathrm{GFP}^{+}$neurons $\left(100.2 \pm 6.1 \%, n=6 ; t_{(12)}=3.955, p=0.0019, t\right.$ test), Cre:GFP ${ }^{+}$neurons with $100 \mu \mathrm{m}$ D-serine $\left(164.8 \pm 15.3 \%, n=8 ; t_{(14)}=0.7032, p=0.4934, t\right.$ test). Right, cumulative distribution of experiments. Data represent mean $\pm \mathrm{SEM}, * p<0.05$. ns, not significant.

rate of GluN2B surface diffusion and decreases residence at postsynaptic sites (Papouin et al., 2012; Ferreira et al., 2017), which may be required for LTP (Dupuis et al., 2014). Thus, loss of Dserine at synaptic sites by the removal of SR may alter the balance of synaptic GluN2 subunits through changes in trafficking mechanisms and have complex effects on synaptic plasticity.

\section{Autocrine mode of D-serine action?}

The postsynaptic localization of SR and the cell-autonomous regulation of NMDAR function by neuronal SR suggest the local postsynaptic release and autocrine mode of D-serine action at synapses. For example, in addition to pyramidal neurons, SR and D-serine localize to GABAergic neurons (Miya et al., 2008; Curcio et al., 2013; Balu et al., 2014; Lin et al., 2016; Takagi et al., 2020), arguing against D-serine being released presynaptically as a cotransmitter. Furthermore, recent work suggests that postsynaptic SR activity is tightly regulated by AMPAR and NMDAR
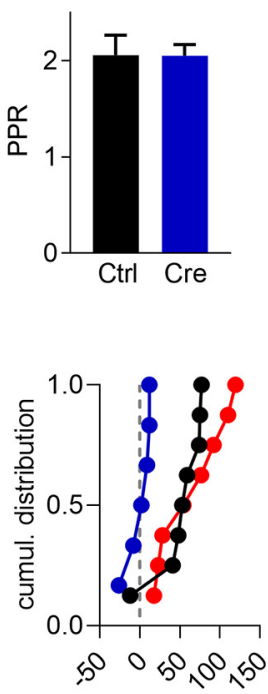

$\Delta$ from baseline (\%) activity (Balan et al., 2009; Ma et al., 2014; Lin et al., 2016). An autocrine mode of Dserine action is also supported by the identification of D-serine transporters in neurons. Alanine-serine-cysteine transporter 1 (Asc-1) is a neutral amino acid transporter located in neurons (Helboe et al., 2003; Matsuo et al., 2004) that can mediate the bidirectional transport of D-serine while exchanging with other small neutral amino acids (Fukasawa et al., 2000). Stimulating the antiporter activity of Asc-1 by the addition of D-isoleucine induces release of neuronal D-serine from cultured neurons, and enhances LTP in acute hippocampal slices (Rosenberg et al., 2013; Sason et al., 2017). Additionally, inhibition of Asc-1 decreases both D-serine uptake and release and inhibits LTP in CA1 (Sason et al., 2017). However, Asc-1 also transports other amino acids, including glycine and L-serine, which complicates interpretation of its effects (Fukasawa et al., 2000). Furthermore, the subcellular localization of Asc-1 is not known. Recently, the system A-type glutamine transporter SNAT1 has been proposed as a candidate neuronal reuptake transporter for D-serine (Bodner et al., 2020), although the precise localization of SNAT1 is also not known.

\section{High levels of nonsynaptic SR}

As we show here (Fig. 1), SR immunoreactivity is curiously high in nonsynaptic locations, notably the soma and dendrites, but for what purpose? The broad distribution of SR at P16 might indicate imprecise regulation of D-serine release before the compartmentalization of glycine at extrasynaptic NMDARs and D-serine to synaptic NMDARs (Gray and Nicoll, 2012; Papouin et al., 2012), and might explain the lack of effects of single-cell SR deletion at P16 (Fig. 5). However, evidence suggests that both nuclear and dendritic localization of SR downregulates its activity. For example, following apoptotic insult, SR translocates to the nucleus independent of NMDAR activity where its racemase activity is inhibited to limit apoptotic damage (Kolodney et al., 2015). Interestingly, in addition to its function as a racemase, SR can also function as an eliminase, catalyzing the $\alpha, \beta$ elimination of water from both Lserine (Strisovsky et al., 2003) and D-serine (Foltyn et al., 2005) to form pyruvate. At least in vitro, SR produces threefold more pyruvate than $\mathrm{D}$-serine, suggesting that the eliminase activity is dominant (Panizzutti et al., 2001; Foltyn et al., 2005). Indeed, these dueling activities of SR may function to limit intracellular D-serine levels (Foltyn et al., 2005). Because its racemase activity can be controlled by post-translational modifications and protein-protein interactions (Balan et al., 2009; Foltyn et al., 2010; Ma et al., 2014), and racemase and eliminase activity are differentially controlled by coenzyme availability (Strisovsky et al., 2003), SR may have pleotropic roles dependent on subcellular localization. 
Nevertheless, this study does not ultimately distinguish between SR racemization and elimination.

In conclusion, our data show the postsynaptic localization of SR in hippocampal CA1 pyramidal neurons and the cell-autonomous regulation of NMDARs by neuronal SR. These results support an autocrine mode of $\mathrm{D}$-serine following postsynaptic release. Indeed, the concept of postsynaptic release of neuromodulators is not new. For example, BDNF is released postsynaptically during synaptic plasticity (Harward et al., 2016; Hedrick et al., 2016). However, further studies are needed to identify the mechanisms regulating $\mathrm{D}$-serine postsynaptic release and termination of $\mathrm{D}$-serine action within the synaptic cleft.

\section{References}

Balan L, Foltyn VN, Zehl M, Dumin E, Dikopoltsev E, Knoh D, Ohno Y, Kihara A, Jensen ON, Radzishevsky IS, Wolosker H (2009) Feedback inactivation of $\mathrm{D}$-serine synthesis by NMDA receptor-elicited translocation of serine racemase to the membrane. Proc Natl Acad Sci USA 106:7589-7594.

Balu DT, Li Y, Puhl MD, Benneyworth MA, Basu AC, Takagi S, Bolshakov VY, Coyle JT (2013) Multiple risk pathways for schizophrenia converge in serine racemase knockout mice, a mouse model of NMDA receptor hypofunction. Proc Natl Acad Sci USA 110:E2400-2409.

Balu DT, Takagi S, Puhl MD, Benneyworth MA, Coyle JT (2014) D-serine and serine racemase are localized to neurons in the adult mouse and human forebrain. Cell Mol Neurobiol 34:419-435.

Balu DT, Li Y, Takagi S, Presti KT, Ramikie TS, Rook JM, Jones CK, Lindsley CW, Conn PJ, Bolshakov VY, Coyle JT (2016) An mGlu5-positive allosteric modulator rescues the neuroplasticity deficits in a genetic model of NMDA receptor hypofunction in schizophrenia. Neuropsychopharmacology 41:2052-2061.

Balu DT, Presti KT, Huang CC, Muszynski K, Radzishevsky I, Wolosker H, Guffanti G, Ressler KJ, Coyle JT (2018) Serine racemase and D-serine in the amygdala are dynamically involved in fear learning. Biol Psychiatry 83:273-283.

Basu AC, Tsai GE, Ma CL, Ehmsen JT, Mustafa AK, Han L, Jiang ZI, Benneyworth MA, Froimowitz MP, Lange N, Snyder SH, Bergeron R, Coyle JT (2009) Targeted disruption of serine racemase affects glutamatergic neurotransmission and behavior. Mol Psychiatry 14:719-727.

Benneyworth MA, Li Y, Basu AC, Bolshakov VY, Coyle JT (2012) Cell selective conditional null mutations of serine racemase demonstrate a predominate localization in cortical glutamatergic neurons. Cell Mol Neurobiol 32:613-624.

Bergeron R, Meyer TM, Coyle JT, Greene RW (1998) Modulation of Nmethyl-D-aspartate receptor function by glycine transport. Proc Natl Acad Sci USA 95:15730-15734.

Bischofberger J, Engel D, Li L, Geiger JR, Jonas P (2006) Patch-clamp recording from mossy fiber terminals in hippocampal slices. Nat Protoc 1:20752081.

Bodner O, Radzishevsky I, Foltyn VN, Touitou A, Valenta AC, Rangel IF, Panizzutti R, Kennedy RT, Billard JM, Wolosker H (2020) D-Serine signaling and NMDAR-mediated synaptic plasticity are regulated by system A-type of glutamine/D-serine dual transporters. J Neurosci 40:64896502.

Chen N, Luo T, Raymond LA (1999) Subtype-dependence of NMDA receptor channel open probability. J Neurosci 19:6844-6854.

Chen PE, Geballe MT, Katz E, Erreger K, Livesey MR, O’Toole KK, Le P, Lee CJ, Snyder JP, Traynelis SF, Wyllie DJ (2008) Modulation of glycine potency in rat recombinant NMDA receptors containing chimeric NR2A/ 2D subunits expressed in Xenopus laevis oocytes. J Physiol 586:227-245.

Cummings KA, Popescu GK (2015) Glycine-dependent activation of NMDA receptors. J Gen Physiol 145:513-527.

Curcio L, Podda MV, Leone L, Piacentini R, Mastrodonato A, Cappelletti P, Sacchi S, Pollegioni L, Grassi C, D’Ascenzo M (2013) Reduced D-serine levels in the nucleus accumbens of cocaine-treated rats hinder the induction of NMDA receptor-dependent synaptic plasticity. Brain 136:12161230.
Ding X, Ma N, Nagahama M, Yamada K, Semba R (2011) Localization of Dserine and serine racemase in neurons and neuroglias in mouse brain. Neurol Sci 32:263-267.

Dupuis JP, Ladepeche L, Seth H, Bard L, Varela J, Mikasova L, Bouchet D, Rogemond V, Honnorat J, Hanse E, Groc L (2014) Surface dynamics of GluN2B-NMDA receptors controls plasticity of maturing glutamate synapses. EMBO J 33:842-861.

Ehmsen JT, Ma TM, Sason H, Rosenberg D, Ogo T, Furuya S, Snyder SH, Wolosker H (2013) D-serine in glia and neurons derives from 3-phosphoglycerate dehydrogenase. J Neurosci 33:12464-12469.

Erreger K, Dravid SM, Banke TG, Wyllie DJ, Traynelis SF (2005) Subunitspecific gating controls rat NR1/NR2A and NR1/NR2B NMDA channel kinetics and synaptic signalling profiles. J Physiol 563:345-358.

Ferreira JS, Papouin T, Ladepeche L, Yao A, Langlais VC, Bouchet D, Dulong J, Mothet JP, Sacchi S, Pollegioni L, Paoletti P, Oliet SH, Groc L (2017) Co-agonists differentially tune GluN2B-NMDA receptor trafficking at hippocampal synapses. Elife 6:e25492.

Fischer G, Mutel V, Trube G, Malherbe P, Kew JN, Mohacsi E, Heitz MP, Kemp JA (1997) Ro 25-6981, a highly potent and selective blocker of Nmethyl-D-aspartate receptors containing the NR2B subunit: characterization in vitro. J Pharmacol Exp Ther 283:1285-1292.

Foltyn VN, Zehl M, Dikopoltsev E, Jensen ON, Wolosker H (2010) Phosphorylation of mouse serine racemase regulates D-serine synthesis. FEBS Lett 584:2937-2941.

Foltyn VN, Bendikov I, De Miranda J, Panizzutti R, Dumin E, Shleper M, Li P, Toney MD, Kartvelishvily E, Wolosker H (2005) Serine racemase modulates intracellular D-serine levels through an alpha,beta-elimination activity. J Biol Chem 280:1754-1763.

Foster KA, McLaughlin N, Edbauer D, Phillips M, Bolton A, ConstantinePaton M, Sheng M (2010) Distinct roles of NR2A and NR2B cytoplasmic tails in long-term potentiation. J Neurosci 30:2676-2685.

Fukasawa Y, Segawa H, Kim JY, Chairoungdua A, Kim DK, Matsuo H, Cha SH, Endou H, Kanai Y (2000) Identification and characterization of a Na $(+)$-independent neutral amino acid transporter that associates with the 4F2 heavy chain and exhibits substrate selectivity for small neutral Dand L-amino acids. J Biol Chem 275:9690-9698.

Gray JA, Nicoll RA (2012) Thinking outside the synapse: glycine at extrasynaptic NMDA receptors. Cell 150:455-456.

Gray JA, Shi Y, Usui H, During MJ, Sakimura K, Nicoll RA (2011) Distinct modes of AMPA receptor suppression at developing synapses by GluN2A and GluN2B: single-cell NMDA receptor subunit deletion in vivo. Neuron 71:1085-1101.

Harward SC, Hedrick NG, Hall CE, Parra-Bueno P, Milner TA, Pan E, Laviv T, Hempstead BL, Yasuda R, McNamara JO (2016) Autocrine BDNFTrkB signalling within a single dendritic spine. Nature 538:99-103.

Hedrick NG, Harward SC, Hall CE, Murakoshi H, McNamara JO, Yasuda R (2016) Rho GTPase complementation underlies BDNF-dependent homo- and heterosynaptic plasticity. Nature 538:104-108.

Helboe L, Egebjerg J, Moller M, Thomsen C (2003) Distribution and pharmacology of alanine-serine-cysteine transporter 1 (asc-1) in rodent brain. Eur J Neurosci 18:2227-2238.

Ishiwata S, Umino A, Balu DT, Coyle JT, Nishikawa T (2015) Neuronal serine racemase regulates extracellular D-serine levels in the adult mouse hippocampus. J Neural Transm (Vienna) 122:1099-1103.

Johnson JW, Ascher P (1987) Glycine potentiates the NMDA response in cultured mouse brain neurons. Nature 325:529-531.

Kartvelishvily E, Shleper M, Balan L, Dumin E, Wolosker H (2006) Neuronderived $\mathrm{D}$-serine release provides a novel means to activate N-methyl-Daspartate receptors. J Biol Chem 281:14151-14162.

Kleckner NW, Dingledine R (1988) Requirement for glycine in activation of NMDA-receptors expressed in Xenopus oocytes. Science 241:835-837.

Kolodney G, Dumin E, Safory H, Rosenberg D, Mori H, Radzishevsky I, Wolosker H (2015) Nuclear compartmentalization of serine racemase regulates D-serine production: implications for N-methyl-D-aspartate (NMDA) receptor activation. J Biol Chem 290:31037-31050.

Kremer JR, Mastronarde DN, McIntosh JR (1996) Computer visualization of three-dimensional image data using IMOD. J Struct Biol 116:71-76.

Le Bail M, Martineau M, Sacchi S, Yatsenko N, Radzishevsky I, Conrod S, Ait Ouares K, Wolosker H, Pollegioni L, Billard JM, Mothet JP (2015) Identity of the NMDA receptor coagonist is synapse specific and developmentally regulated in the hippocampus. Proc Natl Acad Sci USA 112: E204-E213. 
Lester RA, Tong G, Jahr CE (1993) Interactions between the glycine and glutamate binding sites of the NMDA receptor. J Neurosci 13:1088-1096.

Li Y, Krupa B, Kang JS, Bolshakov VY, Liu G (2009) Glycine site of NMDA receptor serves as a spatiotemporal detector of synaptic activity patterns. J Neurophysiol 102:578-589.

Li Y, Sacchi S, Pollegioni L, Basu AC, Coyle JT, Bolshakov VY (2013) Identity of endogenous NMDAR glycine site agonist in amygdala is determined by synaptic activity level. Nat Commun 4:1760.

Lin H, Jacobi AA, Anderson SA, Lynch DR (2016) D-Serine and serine racemase are associated with PSD-95 and glutamatergic synapse stability. Front Cell Neurosci 10:34

Ma TM, Paul BD, Fu C, Hu S, Zhu H, Blackshaw S, Wolosker H, Snyder SH (2014) Serine racemase regulated by binding to stargazin and PSD-95: potential N-methyl-D-aspartate-alpha-amino-3-hydroxy-5-methyl-4-isoxazolepropionic acid (NMDA-AMPA) glutamate neurotransmission cross-talk. J Biol Chem 289:29631-29641.

Madry C, Mesic I, Betz H, Laube B (2007) The N-terminal domains of both $\mathrm{NR} 1$ and NR2 subunits determine allosteric $\mathrm{Zn}^{2+}$ inhibition and glycine affinity of N-methyl-D-aspartate receptors. Mol Pharmacol 72:15351544.

Maolanon AR, Risgaard R, Wang SY, Snoep Y, Papangelis A, Yi F, Holley D, Barslund AF, Svenstrup N, Hansen KB, Clausen RP (2017) Subtype-specific agonists for NMDA receptor glycine binding sites. ACS Chem Neurosci 8:1681-1687.

Mastronarde DN (2005) Automated electron microscope tomography using robust prediction of specimen movements. J Struct Biol 152:36-51.

Matsuo H, Kanai Y, Tokunaga M, Nakata T, Chairoungdua A, Ishimine H, Tsukada S, Ooigawa H, Nawashiro H, Kobayashi Y, Fukuda J, Endou H (2004) High affinity D- and L-serine transporter Asc-1: cloning and dendritic localization in the rat cerebral and cerebellar cortices. Neurosci Lett 358:123-126.

Mayer ML, Vyklicky L Jr, Clements J (1989) Regulation of NMDA receptor desensitization in mouse hippocampal neurons by glycine. Nature 338:425-427.

Meunier CN, Dallerac G, Le Roux N, Sacchi S, Levasseur G, Amar M, Pollegioni L, Mothet JP, Fossier P (2016) D-Serine and glycine differentially control neurotransmission during visual cortex critical period. PLoS One 11:e0151233.

Miller RF (2004) D-Serine as a glial modulator of nerve cells. Glia 47:275283.

Miya K, Inoue R, Takata Y, Abe M, Natsume R, Sakimura K, Hongou K, Miyawaki T, Mori H (2008) Serine racemase is predominantly localized in neurons in mouse brain. J Comp Neurol 510:641-654.

Mothet JP, Parent AT, Wolosker H, Brady RO Jr, Linden DJ, Ferris CD, Rogawski MA, Snyder SH (2000) D-serine is an endogenous ligand for the glycine site of the N-methyl-D-aspartate receptor. Proc Natl Acad Sci USA 97:4926-4931.

Neame S, Safory H, Radzishevsky I, Touitou A, Marchesani F, Marchetti M, Kellner S, Berlin S, Foltyn VN, Engelender S, Billard JM, Wolosker H (2019) The NMDA receptor activation by d-serine and glycine is controlled by an astrocytic Phgdh-dependent serine shuttle. Proc Natl Acad Sci USA 116:20736-20742.

Nong Y, Huang YQ, Ju W, Kalia LV, Ahmadian G, Wang YT, Salter MW (2003) Glycine binding primes NMDA receptor internalization. Nature 422:302-307.

Panatier A, Theodosis DT, Mothet JP, Touquet B, Pollegioni L, Poulain DA, Oliet SH (2006) Glia-derived D-serine controls NMDA receptor activity and synaptic memory. Cell 125:775-784.

Panizzutti R, De Miranda J, Ribeiro CS, Engelender S, Wolosker H (2001) A new strategy to decrease $\mathrm{N}$-methyl-D-aspartate (NMDA) receptor coactivation: inhibition of $\mathrm{D}$-serine synthesis by converting serine racemase into an eliminase. Proc Natl Acad Sci USA 98:5294-5299.
Papouin T, Ladepeche L, Ruel J, Sacchi S, Labasque M, Hanini M, Groc L, Pollegioni L, Mothet JP, Oliet SH (2012) Synaptic and extrasynaptic NMDA receptors are gated by different endogenous coagonists. Cell 150:633-646.

Papouin T, Henneberger C, Rusakov DA, Oliet SH (2017) Astroglial versus neuronal D-serine: fact checking. Trends Neurosci 40:517-520.

Perez EJ, Tapanes SA, Loris ZB, Balu DT, Sick TJ, Coyle JT, Liebl DJ (2017) Enhanced astrocytic d-serine underlies synaptic damage after traumatic brain injury. J Clin Invest 127:3114-3125.

Priestley T, Laughton P, Myers J, Le Bourdelles B, Kerby J, Whiting PJ (1995) Pharmacological properties of recombinant human N-methyl-D-aspartate receptors comprising NR1a/NR2A and NR1a/NR2B subunit assemblies expressed in permanently transfected mouse fibroblast cells. Mol Pharmacol 48:841-848.

Rosenberg D, Artoul S, Segal AC, Kolodney G, Radzishevsky I, Dikopoltsev E, Foltyn VN, Inoue R, Mori H, Billard JM, Wolosker H (2013) Neuronal D-serine and glycine release via the Asc-1 transporter regulates NMDA receptor-dependent synaptic activity. J Neurosci 33:3533-3544.

Sason H, Billard JM, Smith GP, Safory H, Neame S, Kaplan E, Rosenberg D, Zubedat S, Foltyn VN, Christoffersen CT, Bundgaard C, Thomsen C, Avital A, Christensen KV, Wolosker H (2017) Asc-1 transporter regulation of synaptic activity via the tonic release of $\mathrm{d}$-serine in the forebrain. Cereb Cortex 27:1573-1587.

Schell MJ, Molliver ME, Snyder SH (1995) D-serine, an endogenous synaptic modulator: localization to astrocytes and glutamate-stimulated release. Proc Natl Acad Sci USA 92:3948-3952.

Schell MJ, Brady RO Jr, Molliver ME, Snyder SH (1997) D-serine as a neuromodulator: regional and developmental localizations in rat brain glia resemble NMDA receptors. J Neurosci 17:1604-1615.

Stern P, Behe P, Schoepfer R, Colquhoun D (1992) Single-channel conductances of NMDA receptors expressed from cloned cDNAs: comparison with native receptors. Proc Biol Sci 250:271-277.

Strisovsky K, Jiraskova J, Barinka C, Majer P, Rojas C, Slusher BS, Konvalinka J (2003) Mouse brain serine racemase catalyzes specific elimination of L-serine to pyruvate. FEBS Lett 535:44-48.

Takagi S, Puhl MD, Anderson T, Balu DT, Coyle JT (2020) Serine racemase expression by striatal neurons. Cell Mol Neurobiol Advance online publication. Retrieved May 22, 2020. doi: 10.1007/s10571-020-00880-9.

Ting JT, Lee BR, Chong P, Soler-Llavina G, Cobbs C, Koch C, Zeng H, Lein E (2018) Preparation of acute brain slices using an optimized N-methylD-glucamine protective recovery method. J Vis Exp 132:53825.

Wolosker H, Blackshaw S, Snyder SH (1999) Serine racemase: a glial enzyme synthesizing D-serine to regulate glutamate-N-methyl-D-aspartate neurotransmission. Proc Natl Acad Sci USA 96:13409-13414.

Wolosker H, Panizzutti R, De Miranda J (2002) Neurobiology through the looking-glass: $\mathrm{d}$-serine as a new glial-derived transmitter. Neurochem Int 41:327-332.

Wolosker H, Balu DT, Coyle JT (2016) The rise and fall of the d-serine-mediated gliotransmission hypothesis. Trends Neurosci 39:712-721.

Wolosker H, Balu DT, Coyle JT (2017) Astroglial versus neuronal D-serine: check your controls! Trends Neurosci 40:520-522.

Yang JH, Wada A, Yoshida K, Miyoshi Y, Sayano T, Esaki K, Kinoshita MO, Tomonaga S, Azuma N, Watanabe M, Hamase K, Zaitsu K, Machida T, Messing A, Itohara S, Hirabayashi Y, Furuya S (2010) Brain-specific Phgdh deletion reveals a pivotal role for L-serine biosynthesis in controlling the level of $\mathrm{D}$-serine, an $\mathrm{N}$-methyl- $\mathrm{D}$-aspartate receptor co-agonist, in adult brain. J Biol Chem 285:41380-41390.

Yang Y, Ge W, Chen Y, Zhang Z, Shen W, Wu C, Poo M, Duan S (2003) Contribution of astrocytes to hippocampal long-term potentiation through release of D-serine. Proc Natl Acad Sci USA 100:15194-15199.

Yoshikawa M, Takayasu N, Hashimoto A, Sato Y, Tamaki R, Tsukamoto H, Kobayashi H, Noda S (2007) The serine racemase mRNA is predominantly expressed in rat brain neurons. Arch Histol Cytol 70:127-134. 